\title{
10 The Battle over a Fair Share: The Creation of Labour Market Institutions in Norway
}

\author{
'For there is not ordinarily a greater sign of the equal distribution of anything than that every \\ man is contented with his share'. (Thomas Hobbes, Of the Natural Condition of Mankind as Con- \\ cerning Their Felicity and Misery, Leviathan)
}

Thomas Hobbes is an appealing starting point for a discussion on how power is institutionalized in society. According to Hobbes, the state of nature contains no sustainable foundation for peace and society. It offers man only fear and a solitary life and leaves him in a state of war. For Hobbes, and for many political philosophers after him, the solution to an end to this war, created by nature, was for man to enter into a social contract or agreement, in which power and wealth could be shared. The institutions of society can be regarded as such a social contract. Institutions rest partly on power, partly on the acceptance and support of members of society. Their purpose is to create peace and order and to distribute benefits and burdens. When the institutions fail to fulfil these ends, there is a risk that society falls back into a state of war.

Norway was one of the first countries in Europe to pass a labour law regulating industrial action. The Act relating to labour disputes of 1915 defined and enforced a stable system of working-life institutions which continues to function today, 100 years after the Act was passed. The basic structures of these institutions were developed over a period of 30 years prior to the regulation. A study of this process can give us an understanding of the mechanisms behind institutional change and stability.

\subsection{The Elements of a New Institutional System}

Riots and strikes were the first visible signs of the radical change the industrialization of Western societies brought. The new way of production led to demands for a new distribution of wealth as well as the regulation of rights and duties in the labour market. In 1889 over 300 female workers at a matchstick factory in the Norwegian capital, Christiania, went on strike in protest against horrific and health-damaging working conditions and reduced wages. Like the similar strike in London the year before, the matchstick workers' strike in Norway became an awakening for the broader society. The famous writer and social commentator Bjørnstjerne Bjørnson expressed many people's resentment at a public meeting: 'This Strike and the Strikes hereafter, and all the following Strikes, they shall force the Employers to do right. [...] Now the Matchstick Girl's finger is knocking carefully. But next Time it will be a Man's Fist, 
and again next Time a Sledgehammer'. ${ }^{1}$ The exposure of poor working conditions justified the strikes in the eyes of the public. In broad circles, striking was recognized as a legitimate way to protest and put pressure on greedy or irresponsible employers.

The emergence of industrial action and the building of trade unions were closely connected. The first modern trade unions in Norway appeared around 1870, including the unions of typographers and carpenters. These unions expressed interests common to those of the workers and united and transformed their members' demands into collective action. Although many strikes could rise spontaneously and be 'unorganized', like the one in the matchstick factory, trade unions tried to develop a structured procedure for their collective industrial action. From 1886, the Scandinavian Labour Congresses warned against strike actions outside the unions' control and recommended the use of strikes only in cases where it had proven impossible to reach a 'peaceful solution' to disputes (Ormestad \& Arbeidernes faglige, 1906; Voldgiftskomitéen, 1909). As the number and size of the trade unions grew, employers organized or reorganized older associations in defence (Nilsson, 2001, p. 158). By the turn of the century both workers and employers had established confederations of industry-specific organizations and were able to strengthen cooperation and operate at the national level through The Norwegian Confederation of Trade Unions (LO) and the Norwegian Employers' Confederation (N.A.F.) (Olstad et al., 2009; Petersen, 1950). Stronger organizations led to more predictable industrial action and larger strikes and lockouts.

Neither disputes or negotiations, nor strikes or riots, were new phenomena. What was new was the objective of the unions: to obtain a collective agreement with the employer or the employer's organization. It is difficult to establish when the first collective agreement was settled in Norway. As all kinds of matters could be disputed, such as wages, working hours, competence, dismissals or harassment, it may be difficult to establish whether an agreement existed or not, whether it was written or unwritten or who the parties to the agreement were. A dispute was often settled by the employer entering into an agreement with each individual worker. Many enterprises or trades had for a long time had a common wage scale and a regulation of working hours, but these were established by the employer alone. When the unions became stronger, they demanded agreements on wages and working conditions on behalf of their members. In the beginning the employers resisted, but eventually they gave in. In 1889 the union of typographers in Christiania and The Book Printer Association entered into one of the first collective agreements in Norway on wages and other regulations between two member organizations (Ording, 1932, p. 85).

This was four years after a similar collective agreement was signed in Denmark (Nilsson, 2001, p.160). The emergence of the collectiveagreement was a gradual process

1 Bjørnstjerne Bjørnson in Christiania Arbeidersamfund (cit. Olstad, Hansen, \& Aaslund, 2009, p. 16). My translation. 
that took place in many countries and involved the exchange of ideas across borders. In Scandinavia, unions and socialist parties in the three countries coordinated their policy and strategy in biannual Scandinavian Labour Congresses starting in 1886. The Danish labour movement dominated in number and achievements (Nilsson, 2001, p. 160). When strikes became an international phenomenon in the 1880 s, Norwegian newspapers broadly covered strikes in other countries, and the unions exchanged experiences and support with unions abroad. The international flow of impressions and ideas, and the organized collaboration across borders, can explain similarities in institutions and synchronous development in different countries. Not until the unions were well-organized and able to enforce the maintenance of the collective agreements did they attain a de facto legal significance. This was the case in England around 1890 and in Scandinavia the following decade. In Germany and France, collective agreements became common at the beginning of the $20^{\text {th }}$ century (Alsos, Seip, \& Nygaard, 2016, p. 28).

If strikes were the first, then collective agreements were a second element in the institutional system that took form in the labour market. In Norway, as in other countries, these agreements had no direct link to the existing legal regulation. They were extrajudicial and were in the beginning adhered to only as far as the parties were able to enforce them. In England this was stated in the 1871 Trade Union Act, and in Sweden, some legal scholars at the end of the $19^{\text {th }}$ century regarded collective agreements not legally binding (Adlercreutz, 1954, p. 2; Berg, 1930, p. 157).

Through these agreements, a third element was constituted: the organized parties to the agreements. Until collective agreements came into use, the only nexus between employer and employee went through individual contracts. This placed workers in a vulnerable position. The collective agreements, on the other hand, constituted agents in the labour market, with significant influence on the cost of labour and the ways of production. The parties to the collective agreements on both sides did as much as they could to get control over the means of industrial action, and to a certain extent they were able to guarantee peace on behalf of their members.

The three elements together - industrial action, collective agreements and organized parties to the agreements - established an institutional system for the regulation of the labour market, with a potential to become a dominant factor in industrial society.

\subsubsection{Collective Agreements as a Road towards Industrial Peace}

Today we take collective agreements for granted. In the first decades they were in use, one could not. One of the reasons was the uncertainty that followed the legal status of collective agreements (Adlercreutz, 1954; Undén, 1912). In Scandinavia, the first significant collective agreement between two organizations was signed in Denmark in 1885 after a five-month-long lockout. The newly started organization 
of iron manufacturers had to acknowledge the right of the workers to organize and the unions' right to sign agreements on behalf of the workers (Due, Steen Madsen, \& Strøby Jensen, 1993, p. 67f.). In return employers got peace. There was, however, no guarantee that the peace would last. According to what right could a union sign on behalf of its members? Who was bound by a collective agreement, and what happened if one of the parties decided to take industrial action to alter an agreement? No one had a clear answer to such questions, and the system rested on the parties' will to stick to the agreements. However, the function of the collective agreements was to secure industrial peace and fixed wages during the validity period of the agreement. Hence, the peace duty had been the core object of the signing parties from the beginning (Undén, 1912, p. 187).

The institutional framework in the Norwegian society, the existing legal structure with its laws and legal courts, did not correspond fully with the industrial action and the collective agreements. Strikes and lockouts were not regulated as collective action. The contract law regulating individual employment contracts proved insufficient when unions applied mass resignations and blockades. Legal uncertainty connected to whether and how a collective agreement was binding prevented the parties from bringing disputes concerning existing collective agreements before a legal court. Society did not offer any proper means to solve disputes over collective agreements, and could therefore not contribute to peace in the labour market.

Private arbitration was a solution widely discussed in Scandinavia as an alternative to legislation. The Swedish Trade Union Confederation was against the use of arbitration courts. In Denmark however, such institutions were set up in connection with agreements in different trades and industries, and in 1899 the Danish LO and the Danish employers' association established an arbitration court as part of the so-called September Compromise (Septemberforliget) (Due et al., 1993, p. 80). Three years later, in Norway, LO accepted an invitation from its employer counterpart, N.A.F., to conclude an agreement on mediation and arbitration. The 1902 agreement between LO and N.A.F. imposed mediation at the organizational peak level before industrial action was taken and gave the parties an opportunity to bring a dispute before an arbitration board with representation from both sides and a neutral leader. In disputes concerning a valid collective agreement, arbitration was to be compulsory (Alsos et al., 2016, p. 42). The agreement was terminated in 1905, but the provisions on arbitration were continued in the different collective agreements.

The use of arbitration to prevent disputes over existing agreements from ending in strikes or lockouts was a goal for the employer federations in both Norway and Denmark (Martin \& Swank, 2012, p. 61). For the unions, the support for arbitration came out of weakness (Olstad et al., 2009, p. 40). In the early years of the $20^{\text {th }}$ century, the Norwegian LO was weak and lost battles to the employers. In absence of legislative regulation of the collective bargaining and the agreements, an agreement on arbitration to resolve legal disputes was a second best option. 
In the state of war between unions and employers, collective agreements were a temporary truce. This made the agreements socially acceptable and even desirable. Since the legislation could not contribute much to the maintenance of the truce, the labour market parties used collective agreements to regulate action on the battlefield as well. This was the case in the Danish September Compromise, and it was the case in the agreements of 1902 on mediation and arbitration in Norway. However, the system rested on the balance of power between the parties. This led to a consolidation of power under peak organizations on both sides, and by 1910, the Norwegian LO and the N.A.F. represented a considerable part of the industrial workforce and industries. The N.A.F. had taken important control over the collective agreements on the employer side, and LO had established a grip on the strike funds on the labour side (Alsos et al., 2016, pp. 33ff.). Although the strikes and lockouts became more predictable, following renegotiations of agreements, the industrial action grew in size and impact. In the summer of 1911, 44,000 workers were directly affected by lockout or strike. This was more than 70 per cent of the workers employed in N.A.F.'s member enterprises.

During the 1911 industrial lockout Norway was in a state of war. The liberal and socially oriented politician Johan Castberg reacted to the comprehensive lockout and strikes affecting workers as well as families and children during the summer. He wanted society to 'create [legal] institutions [...] instead of this wild war' he saw between unions and employers (cit. Alsos et al., 2016, p. 50).

\subsection{The Role of the State in Institution Building}

In the academic discussion on the role of the state in the construction of industrial relations institutions, Chris Howell has thrown light on the importance of state intervention through legislation and mediation in the case of England. After more than a decade of judicial court intervention in industrial action, hostile toward trade unions, a liberal government granted unions immunity for actions taken in connection with a trade dispute in the 1906 Trade Dispute Act (Howell, 2007, p. 62). Howell sees this and other state measures as significant to the construction of what he calls The Collective Laissez-Faire System of British industrial relations between 1890 and 1940. This was a laissez-faire system based upon industry-level bargaining, often described as a voluntarist system without state intervention. However, Howell argues that the system was actively conducted by the state, 'either indirectly through persuasion and mediation during disputes, or directly [...] through trade boards' (Howell, 2007, p. 80). In England, the state promoted the construction of bargaining structures rather than a legislative framework for industrial relations.

Until the summer of 1911, it looked like Norway would follow the same path as England, perhaps lagging a bit behind. The Norwegian Parliament (Stortinget) failed in 1903 to adopt a law that recognized and protected the unions, and the only regulation of the existing bargaining system was the remains of the 1902 agreement 
between LO and N.A.F. concerning the principles of compulsory arbitration in legal disputes over collective agreements.

Two factors shaped a development in Norway different from the one in England. Nationwide industry-level bargaining did not exist before 1907. The first nation-wide collective agreement in Norway was signed by the Norwegian Union of Iron and Metal Workers in 1907 and became a model for agreements in other industries. However, the system of geographically divided agreements was maintained, and this made room for federations to grow on both sides. LO became the coordinating actor on the employee side, whereas N.A.F. deliberately seized control of the trade organizations on the employer side. In the beginning LO had competition from some of the larger unions, but in the course of a decade, LO and N.A.F gained control of the organized labour market, and by 1910, there was no external threat to the two.

Yet, from inside LO a radical opposition appeared in late 1911. That year had brought the largest labour market conflicts ever in Norway. The employers wanted a comprehensive but short conflict in order to drain the union's strike funds in one big sweep. Over 44,000 workers were affected in several lockouts during the spring. This was more than 70 per cent of the workers covered by collective agreements in Norway (Justisdepartementet, 1912, p. 7). Political mobilization from left to right forced the prime minister to engage the parliament as mediator in the conflict between $\mathrm{LO}$ and N.A.F. A settlement, based on mediation and arbitration, was accepted by the unions, but not without resistance. It lifted to the surface an opposition to the whole system of collective agreements and regulated industrial action inside LO itself. The Trade Union Opposition of 1911 (Fagopposisjonen av 1911) publicized its programme in November 1911. It wanted to abolish collective agreements and concentrate on industrial action rather than negotiations (Bjørnson, Kokkvoll, Sverdrup, Jensen, \& Bull, 1990). The opposition was from the beginning geographically based in industry and trade around Trondheim, but received support especially from mobile construction workers and workers in newly established industrial towns. Hence, LO and the labour movement had to deal with an internal opposition with a programme pointing toward revolution.

The existence of two large umbrella organizations, LO and N.A.F., representing what was regarded as the interests of two classes in society, and an emerging revolutionary opposition in the trade unions, were by moderate politicians seen as an opportunity and a cause to end the rising level of industrial conflict by state regulation. After the turbulent spring of 1911, with no end to the conflict before the state intervened and mediated a settlement, the Storting asked the government to introduce a bill on compulsory mediation and arbitration in labour conflicts (Justisdepartementet, 1912, p. 2). The topic had already been scrutinized in a report commissioned by the government, published in 1909. When the liberal judge in the Maritime Court, Paal Berg, in 1911 was commissioned by the government to write the proposal, he could build on the report from 1909. The government and the Storting had decided to search for a solution where the state could play an active role in the war between labour and capital. 


\subsubsection{Three Problems and the Search for a Political Solution}

The political debate in Norway on state intervention and regulation of the disputes between labour and capital circled around three main problems: a power problem, a social problem and a democratic problem.

The power problem concerned cohesion and control over the unions and the employers. Should the state engage in the struggle between the social classes? And if so, would the parties in the labour market show commitment and have capacity to comply with a regulated system of collective agreements? How should the state establish a third-party function that could bring stability to the dispute settlement?

Industrial action was seen not only as wage disputes, but was regarded as a social problem as well. Social despair originated from the consequences of industrial production and labour's share of profit. An increasing part of the population had low income and lacked social security. The large strike conflicts added misery to the families and third parties affected by the fights. Politicians, like Johan Castberg, saw social instability as a threat to society and wanted to use the state to bring an end to the fighting. This view found wide support. Others were critical and wanted to leave the market forces in business untouched. If the state should contribute to arbitrations in wage disputes, a highly relevant question was whether social aspects, like living conditions, should have relevance for wage-setting in a market. To what extent could the state intervene in the labour market to create social justice without causing market imbalance or social upheaval?

The question concerning state intervention also raised a democratic problem. Who were the legitimate representatives of the workers and employers in the labour market? To what extent should the larger organizations be given preference over minor actors? Should collective interests have primacy over individual interests? These questions addressed the democratic problem of identifying legitimate interests in a labour market.

There were no easy solutions to the three problems, and it proved difficult to create a political majority in the Storting behind a strategy to regulate industrial action. The liberal party, Venstre, was a heterogeneous party with support from different social layers and with a legacy in social politics. The party had a left-wing sister party (Arbeiderdemokratene) which led in social matters. The idea of a state taking a position above the class struggle was central to the party. In Venstre we find the greatest supporters of state intervention. This view often went together with a fundamental trust in the judicial system and belief that the courts could be used as a key to create social justice. Venstre supported the use of compulsory mediation and compulsory arbitration in disputes of interests to prevent industrial action (Aasland, 1961, p. 36; Alsos et al., 2016, p. 49). When in government in 1908, Venstre commissioned, as mentioned above, the first report on the issue (Voldgiftskomiteen, 1909). 
The conservative party, Høire, did not support the use of compulsory arbitration in labour conflicts. The party was in general sceptical to state intervention in business and did not want to support anything that could strengthen the position of the trade unions (Alsos et al., 2016, p. 333). However, Høire lent its ear to the employer organization and in the end supported the policy for a law regulating compulsory mediation.

At the left side of politics, Arbeiderpartiet, the Labour Party, was gaining support. In 1912 it got 26 per cent of the votes in the general election. The party's representation at the Storting increased from 5 to 23 members, and Arbeiderpartiet became larger than Høire. The party was closely connected to LO, where all union members were jointly registered as members of the party. Consequently, Arbeiderpartiet defended the right to organize and to take industrial action. It did not refuse all state intervention and regulation, but sought a regulation which left the right to organize and strike untouched (Alsos et al., 2016).

When Paal Berg started the work with the government proposal for a new act relating to labour disputes in 1911, he built upon a report from Voldgiftskomiteen (the arbitration commission). LO and N.A.F. had taken part in the commission's work, and the opinions of the labour market parties were clear. LO and N.A.F. supported the introduction of a mediation institution and would welcome arbitration in disputes of law, concerning the validity, interpretation or existence of a collective agreement. However, LO and N.A.F. dismissed the idea of arbitration used in disputes of interests. The distinction between disputes of interests and disputes of law was essential to the two parties.

Paal Berg followed their view. In his work on the bill, he decided to introduce two arbitration boards rather than one, one for disputes of interest and one for disputes of law. The former should be engaged if the two parties to a dispute voluntarily brought the dispute forward; the latter should be engaged if one of the parties experienced a breach to an agreement. The settlements of disputes of law were better handled in a court-like institution, Berg argued. Decisions could then serve as a precedent, and the labour law could develop over time. This required a permanent court with appointed judges, not an ad hoc arbitration board (Justisdepartementet, 1912).

In the 1912 bill on the regulation of labour disputes, the government proposed establishing a mediation institution to help the parties reach understanding before industrial action were taken and also a labour court that could judge in disputes of law. This was in line with the wishes of the labour market parties. However, the two organizations did not support the proposition and complained that they were not heard before the bill was finished. In LO, the radical wing had grown, and its supporters did not want a labour dispute law at all. LO therefore went against the law introducing a labour court. On the employer side, the organization had objections to how the mediation should be organized.

The lack of support from LO caused Arbeiderpartiet to oppose the bill. So did Venstre, but for another reason. The current bill failed to establish a permanent 
arbitration board for use in disputes of interests. Only this could bring down the number of large industrial conflicts, the liberal party argued (Alsos et al., 2016, p. 74). The Storting decided in 1912 to postpone the law, and it took three more years, and several proposals, before an act relating to labour disputes was eventually passed in 1915. It did not happen without conflict, however. The liberal government tried to force through a law that included compulsory arbitration in larger labour conflicts. LO threatened with general strike. With an election ahead, the government gave in and took the arbitration clause out of the proposal. A labour dispute act was then passed with support from all parties in the Storting (Alsos et al., 2016, p. 84).

\subsubsection{The Law and the Institutions}

The Act relating to the labour disputes of 1915 recognized collective agreements and defined them legally. The parties to a collective agreement were now bound by it by law, and the collective agreements were given primacy over individual employment contracts. A peace obligation was introduced in cases of disputes of law, and industrial action became prohibited as long as a collective agreement was in force and until compulsory mediation had taken place. This was a legal recognition of the existing labour market organizations and institutions, and it was a de facto acknowledgement of the organizations' right to industrial action.

Furthermore, the Act introduced compulsory mediation by an official mediator before any industrial action was taken. From its start in 1916 this institution would become very important for the negotiating parties, with between 100 and 200 disputes mediated every year during the first decade (Nergaard, 2016, p. 33).

In accordance with the commission report of 1909 and the earlier law proposals, the Labour Dispute Act of 1915 built on the important distinction between disputes of interests and disputes of law. A dispute of interest was defined as a dispute concerning 'the regulation of terms of employment or wages or other matters relating to employment which are not covered by a collective agreement' (Labour Dispute Act $1915, \S 6)$. As mentioned, the organizations strongly opposed the use of compulsory arbitration in such cases, and the liberal government did not succeed in incorporating an arbitration board for disputes of interests into the law in 1915. However, a temporary arbitration law was passed the following year, justified as a wartime regulation, but was reintroduced several times until 1922 (Alsos et al., 2016, p. 130f.). At irregular intervals, state intervention and the use of arbitration has since then been part of the Norwegian wage-setting system, handled as ad hoc regulations separated from the labour dispute legislation.

To handle disputes of law, what the act defined as disputes 'concerning the validity of a collective agreement, interpretation or existence of a collective agreement, or demands founded on a collective agreement', a labour court, Arbeidsretten, was set up with judges appointed by the government. The leader of the Labour Court should 
have the qualification of a justice of the Supreme Court. The other two judges should be appointed after a nomination by the major labour market parties. Hence the court would bear resemblance to an arbitration board (Labour Dispute Act 1915, §§ 6-12).

The first ten years, the chairman of the court was the only member not nominated by LO or N.A.F., and his vote was often decisive in the cases. The chairman was Paal Berg, the same judge who wrote the first draft of the government's proposal of a labour dispute law in 1911. In 1927, the court was extended with two neutral judges in an amendment of the Labour Dispute Act. With three neutral judges, the court's decisions became more difficult to challenge. Nevertheless, from the first day of the court's work, the chairman managed to give rulings that set precedence for subsequent cases; hence the court's rulings were often unanimous (Alsos et al., 2016, p. 118).

\subsubsection{Central Power and Fringe Battles}

One consequence of the Labour Dispute Act was that the central power of LO and N.A.F. increased. The control over unions and employers was strengthened when the agreements were legally regulated. This was a first step towards a solution to the power problem. The collective agreements were a valuable asset to the organizations and in many ways their raison d'être. The act invested the two parties with power when the collective agreements were legally acknowledged and subordinated state jurisdiction.

The right to nominate judges to the Labour Court, given to LO and N.A.F., invited commitment to and responsibility for the institutional system. The imposed peace obligation did of course bind the umbrella organizations LO and N.A.F., but at the same time it made it much easier for the two to control and coordinate the individual unions and employers. In the two decades following the act, this became a central task, not least for LO.

The social problems, created by industrial action, were not solved by just passing a law. However, the recognition of the labour movement and its means through the legislation, promoted social inclusion and trust in the system; collective agreements became a legitimate instrument through which to establish fair wages. The regulation of the industrial action through peace duty added an element of regularity and predictability to the labour conflicts. It was, however, the use of state intervention and arbitration that contributed most to labour peace during the years with high inflation under World War I and the years of deflation that followed. The times of hunger and poverty were not ended by legislation, and radical and revolutionary thoughts held a grip on many Norwegians during the two decades after 1915.

The democratic problem concerning representation of the parties in the labour market was partly solved through the Labour Dispute Act. The Act acknowledged the two central organizations as legitimate representatives of interests in the labour market. This was a de facto political recognition of class interests where the collective 
interests were given primacy over individual rights. Nor should the corporatist element in the legislative process be neglected. LO and N.A.F. were highly involved in the preparation of the law, and their resistance to state intervention in disputes of interests was heard, although overruled temporarily in periods. This collaboration between the state and organized interests in the establishment of labour market institutions in Norway became later a modus for legislative process and state ruling in other sectors as well.

The legislation soon appeared to support centralization. Even the radical opposition inside the trade union confederation LO came to shift policy. The Trade Union Opposition of 1911 had grown rapidly, nursing the contempt for class collaboration and, after 1917, a dream of revolution. In 1917, the opposition demanded the abolishment of collective agreements, which were seen as a 'disaster' brought upon the workers when the right to self-determination of the unions was 'sold ... for years at a time'. ${ }^{2}$ The year after, the men of The Trade Union Opposition took over the leading positions in the Labour Party and in two major trade unions. ${ }^{3}$ By 1920, they had taken control over the secretariat of LO, although the former moderate leader, Ole O. Lian, retained his seat. What is noteworthy is that LO and the large unions for the most part continued to defend collective agreements and the legally based institutions throughout the turbulent 1920s. Year by year the Labour Court had to handle industrial conflicts. Many of these were illegal and organized ad hoc outside the formal trade unions to prevent the trade unions from becoming liable for damages. The leadership of LO had to balance between acting responsibly and according to the legal regulation on one hand and silently or indirectly supporting strike-willing members on the other to keep the ranks intact and avoid division. These fringe battles could be significant, and at times the confidence in the labour market institutions could be challenged (Alsos et al., 2016, p. 133). But LO stood by the Labour Court, and when necessary its leader met with the leader of N.A.F. incognito to sort out the problems. Well into the 1930s, the internal tension in LO was coloured by the front between communistoriented members and members supporting the social democratic Labour Party. When the Labour Party formed a government in 1935, LO was well embedded in power. The leader of LO's legal office, Trygve Lie, was appointed Minister of Justice, and the close tie between the trade union confederation and the party leadership was now a link to the government. But this was a link that went the other way as well. The Labour Party did not look forward to governing a country where minor groups could jeopardize the

\footnotetext{
2 'Ulykken med den gamle fagbevægelse er at den gjennem bindende avtaler har solgt arbeidernes organisationsmæssige selvbestemmelsesret for aaremaal ad gangen'. Mindretallets indstilling, Fagorganisationen. Dens formaal, former og taktik, Innstilling fra 15-mandskomiteen, s. 70, trykket i A.F.L., Ekstraordinær kongress 1917, Dagsorden og protokoll.

3 The Norwegian Arbeidsmandsforbund and The Norwegian Union of Iron and Metal Workers (Alsos et al., 2016, p. 116).
} 
labour market and create divisions among voters (Bjørnhaug, Halvorsen, Hansen, \& Aaslund, 2009, p. 62). The party had an interest in strengthening LO's central power.

In 1935 LO and N.A.F. signed the Basic Agreement. This was an agreement on topics not regulated in the Labour Dispute Act. For some years, the employers and the government had put pressure on LO to accept the regulation of referendums in connection with wage settlements. The Basic Agreement addressed this concern and introduced a regulation on how to handle disputes and the unions' representation in the workplace as well. The two organizations wanted to regulate their interaction in agreement rather than have the state regulating the bargaining system by law. Some researchers have seen this agreement as a 'turning point' in the relation between LO and N.A.F. and as an institutional displacement where the battleground of disputes was replaced by cooperation (Falkum, 2015, p. 63). Others have emphasized the importance of more acute political problems and the way the Basic Agreement functioned as a tool to stabilize the different interests inside the labour movement. While workers in export industries found it difficult to strike and weaken their company's relative position in relation to competitors in the world market, workers in sheltered industries could paralyze a whole industry through strikes without putting jobs at risk. This imbalance weakened LO but could be overcome by centralization and central bargaining (Moene \& Wallerstein, 2006, p. 18f.; Terjesen, 2010, p. 80). When Labour came to power, it became important to the party that LO strenghtened control over the unions. The Basic Agreement has been seen as a first step in the labour movement's subordination to the Labour Party and its policy (Olstad, 2010, p. 54). The Basic Agreement brought nothing essentially new but helped LO to take control and eased the centralization and cooperation between LO and N.A.F. that developed during the five years of German occupation in World War II.

\subsection{Why New Labour Market Institutions?}

Labour market institutions were not a new discovery in the late $19^{\text {th }}$ century. Labour relations had been structured through different institutions developed over time. The collective agreement, however, was a new invention. When brought into use, it structured the relation between labour and capital in a different way. To explain this institutional change, we have to search in the historical context for factors influencing the action that shaped the unions and the employers as parties to collective agreements (Abbott, 1997, p. 1154). This institution was brought about by both the development of context and choice by actors. 


\subsubsection{Preconditions for the Institutional Change}

The driving forces behind the strikes and the growth of unions were fuelled by an individual and collective will to oppose individual or class-related oppression created by a change in mode of production as industrialization spread. Economic change, following the rapid growth of the Norwegian economy from 1835 to 1875, displayed an altered distribution of wealth and power and created discontent.

The struggle against oppression was, after the early riots, shaped into a political and economic movement aimed at changing the distribution of wealth under the new way of industrial production. In Max Weber's words, a belief (Vorstellung) in a legitimate order took form (Weber, 1964, p. 124). The ideas and ways of this movement were exchanged across borders. This strengthened the force of the movement and made it possible to gradually force employers to accept a system of collective agreements to set wages and working conditions mutually.

Liberal thoughts and ideas, central to $19^{\text {th }}$-century political thinking, opened a conceptual framework for the forces that drove the building of labour market organizations. In the economic sphere, the abolition or repeal of state privileges and guild regulations opened up the economy for free enterprise (Pollard, 1981, p. 159). Agreements between free citizens became a recognized tool for the regulation of interests. The ideas of economic liberty influenced political and economic thinking in Norway and led to liberalization and growth in the Norwegian economy throughout the $19^{\text {th }}$ century (Bergh $\&$ Hanisch, 1984, p. 42f.). On the political scene, the liberal ideology opened the way for political liberties such as the right to associate and to conclude agreements. These rights legitimized a new political party system and directed the action of the workers through politics and unions. Liberal thoughts and ideology were preconditions for the institutional system that took form.

\subsubsection{Social Struggle and the Role of the State}

When explaining the creation and maintenance of labour market institutions, we shall not underestimate the importance of social struggle. For decades battles were fought in workplaces in different industries before the parties agreed to a collective agreement and proclaimed a truce. The use of power through strikes, dismissal and lockouts made workers and employers defend themselves and turned their actions into bureaucratic structures in the form of organizations. The open use of force made individual and local disputes visible and publicly known. Social problems became part of the political discourse in society and this shaped the political ideas of the labour movement and its political opponents as well. We might say the open political discourse gave the industrial action 'positive feedback' and meaning (Pierson, 2004, p. 19). For each new strike there was a new opportunity to discuss its causes and its effects, and the possibility to explain strikes as something anomalous dwindled away. 
Steadily the organizations gained ground and power. The creation of the first labour market institution in Norway was an ongoing process and not a product of a single crisis.

Even though the open social struggle became a path in institutionalizing the parties' roles in industrial relations, it also became a threat to the system. How long could the society let a battle go on in its midst without using the force of the state? Either by intervention or by ignoring industrial action, the form state regulation took influenced the development of industrial relations systems in industrialized countries (Howell, 2007, p. 41). In Norway the social consequences of industrial action became a significant political topic in parliament starting around 1895. At first, the rising labour movement and radical liberals wanted to use legislation to protect the unions and introduce compulsory mediation in labour disputes. When the strategy failed in 1902, a broad coalition of liberals and farmers looked to the use of state intervention and compulsory arbitration to stop large-scale industrial action. Although direct state intervention did not become a permanent part of the Norwegian industrial relations system, it is still used ad hoc and must be regarded as an important element in the institutional system. By the turn of the $20^{\text {th }}$ century the idea of using state intervention in labour disputes aligned with the new economic view on the labour market and unemployment. Rather than explaining unemployment as caused by individual factors, it could now be recognized as a result of economic fluctuations. Involuntary unemployment could lead to both suffering and immorality, it was argued, which made it both legitimate and necessary to use state power to moderate the market forces and mend the consequences of economic conditions (Seip, 1981, p. 64). State intervention in the labour market became a potential tool in Norwegian economic policy for those who wanted to fight capitalism as well as for those on the other side who wanted to fight the causes of socialism.

When the state eventually intervened in the labour market with legislation on labour disputes, it was after decades of political discussions on the topic. Unfulfilled political programmes were put aside, and legislation was introduced that codified the ideas and practices chiselled out by the two head organizations.

The regulation of labour disputes in Norway was at the same time an institutionalization of cooperation between state and centralized organizations and the beginning of an open corporatist development. The organizations were from the beginning involved in commission work through representation, and through public debate and lobbying, the two major labour market parties made their views heard during the long period of preparation of the law. The inclusion of the organizations in the judicial system through the right to nominate judges to the Labour Court, committed them. Loyalty to state regulation was strengthened during the interwar period. Both workers and employers were at times sceptical. However, efficiency of the judicial system rested upon the parties' commitment. Only organizations could file a case before the Labour Court, and only organizations could be subjects of a lawsuit. The Labour Court was a tool at their disposal, and if the organizations 
lost faith in it, they could decide to negotiate or strike instead of letting the court decide. But the umbrella organizations stuck to the Labour Court, partly because it strengthened their own power and at the same time could take the blame for their own shortcomings.

From an economic point of view, Mancur Olsen has described how large organizations acquire interests that are different from smaller ones (Olson, 1965, 1982). He labelled them encompassing and described why action is changed by size (Olson, 1990, p. 58f.). The collective action of the organizations in Norway and England might thus have developed differently. The establishing in Norway of large organizations with significant influence over the labour market gave the organizations reason to take macro-interests into consideration and power to restrain unions with a narrower view on their members' interests. This made cooperation with the umbrella organizations more relevant to the state, and over time, a nexus between state and corporate interests was established. In England, the absence of a strong central organization made the coordination of interests between unions in different industries more difficult. Hence, the state became more of a mediator between unions through the wage boards than a mediator between labour and capital.

A manifestation of the encompassing interests of $\mathrm{LO}$ in the interwar period was the continuation of LO's commitment to comply with the collective agreements and observe the decisions by the Labour Court, despite the fact that the LO leadership was taken over by the radical opposition, which in its programme had rejected the collective agreements and the Labour Court. The opposition became the defender of the system, although it should be mentioned that in many unions at the industry level, the opposition to the established institution continued to live.

\subsection{Were There Alternatives?}

Were there alternatives to the institutional development of the labour market in Norway? Was the institutional development a self-reinforcing process creating path dependency, or could the organizations and the political actors change its path at any point during the period from 1885 to 1915 (Pierson, 2004)? Even though the development in Norway, which went through stages, made up a path difficult to deviate from, there were occasions where other institutional solutions could have been chosen or where other policies could have won support from the majority.

The Trade Union Opposition of 1911 presented in its programme an alternative to the existing industrial relations institutions. It rejected collective agreements and was against the establishment of a labour court, which it labelled a 'class court' (Alsos et al., 2016, p. 122). From 1918 and 1920, this radical opposition took over the leadership of Arbeiderpartiet and LO, and from the ideology alone, one could expect a policy shift in LO and hostility towards the prevailing labour market institutions. 
But there came no institutional breakdown. The power that LO derived from the labour market institutions was too good to refuse, and LO's leadership continued to support collective agreements and comply with the decisions of the Labour Court. The radical opposition in the trade union movement continued, however, in different forms to advocate a policy against class collaboration until after World War II.

The policy of the Liberal Party (Venstre) represents another alternative institutional path. Against the will of LO and N.A.F, it spoke in favour of a ban on industrial action and the use of compulsory arbitration to solve disputes over interests between labour and capital. This policy did not become institutionalized in the 1915 legislation on labour disputes and is today not part of the legislation. Nevertheless, as mentioned, compulsory arbitration was introduced by the Liberal Party in 1916 and was later used temporarily or as ad hoc legislation. This practice gives the Norwegian bargaining model a different institutional element than, for instance, the Swedish bargaining model, where compulsory arbitration is almost non-existent (Nergaard, Alsos, \& Seip, 2016, p. 53). In the long run, the use of arbitration in Norway did not become the solution for ending larger battles of industrial action, as the Liberal Party had thought. After 1929, the state has used compulsory arbitration in understanding with the larger organizations, not to control them. Compulsory arbitration has been used mostly to bring down minor strikes initiated by small organizations outside LO's control and, in later years, public sector disputes (Stokke, 1997, p. 117; Seip, 2013). The policy of state intervention can be seen as an alternative institutional strategy to voluntary bargaining where the power of the state is actively used to make settlements and preserve peace in the labour market. In Norway this task was for the most part left to organizations and voluntary bargaining. The reason was, probably, that the organizations were highly centralized and capable of exercising power and, to a certain extent, to keep control.

The two umbrella organizations were given a key role in the institutional system established in 1915. This was welcomed by many but regarded as undemocratic by some. Should not smaller organizations or organizations outside LO be represented? In the first proposal of the new law, drawn up by Paal Berg, Berg mentioned the two organizations by name in the proposal. This was later criticized and changed in the next proposal. Instead, the law required a certain number of members to qualify for the right to nominate judges to the Labour Court. This effectively gave the same result. LO was dominant in the private sector and until 1982 was the only organization on the employee side in the private sector that nominated judges (Alsos et al., 2016, p. 375). In the public sector, where a variety of organizations were present and where LO was weaker, a more strictly regulated bargaining system was introduced in 1958 to obtain the centralization. There is reason to believe that the act of 1915 would have institutionalized industrial relations in a slightly different way had LO and N.A.F. not been able to control and coordinate such a large part of the labour market. 


\subsection{Industrial Action and Industrial Peace}

Labour market institutions came as a result of the economic change following industrialization. The same development of organizations and industrial action took place almost simultaneously in many countries. This was a battle over a fair share of production in the new economy. However, the ways in which these battles were carried out could vary, and so could the response of the state (Crouch, 1993).

The first institutions were built by the parties in the labour market. They took the form of a contract on wages and working conditions between unions and employers: a collective agreement. This was not only a settlement of benefits and burdens but a temporary stoppage of war in which each side agreed with the other to suspend aggressive actions. Collective agreements were a road towards peace in the labour market.

When the state decided to regulate labour disputes it was in order to strengthen this aspect of collective agreements. Compulsory mediation and a labour court were introduced in accordance with the wishes of the two head organizations. Hence, trade unions and employer organizations were seen as legitimate representatives of interests in the labour market, and collective agreements were recognized as a tool to regulate wages. This institutional arrangement has prevailed with only minor amendments over 100 years. In concertation with the labour market parties, the state has sought to support the large organizations and has used them as an instrument to implement public income policy and stabilize the economy (Nergaard et al., 2016). This cooperation has not brought a final end to war in the labour market. However, the system has produced a fairly equal distribution of wages in Norway and widespread trust in the existing labour market institutions (NOU 2013:13). This indicates that these institutions fulfil their function and, to rephase Hobbes, share power and wealth in a way that keeps most men contented with their share.

\section{References}

Aasland, T. (1961). Fra arbeiderorganisasjon til mellomparti. Det radikale folkepartis (Arbeiderdemokratenes) forhold til Venstre og sosialistene. Oslo: Universitetsforlaget.

Abbott, A. (1997). Of Time and Space: The Contemporary Relevance of the Chicago School. Social Forces, 75(4), 1149-1182.

Adlercreutz, A. (1954). Kollektivavtalet: studier över dess tillkomsthistoria. Lund: Gleerup.

Alsos, K., Seip, Å. A., \& Nygaard, P. (2016). I arbeidsfredens tjeneste: Arbeidsretten gjennom 100 år. Oslo: Pax.

Berg, P. (1930). Arbeidsrett. Oslo: Norli.

Bergh, T., \& Hanisch, T. J. (1984). Vitenskap og politikk: linjer i norsk sosialøkonomi gjennom 150 år. Oslo: Aschehoug.

Bjørnhaug, I., Halvorsen, T., Hansen, S.-A., \& Aaslund, V. (2009). Medlemsmakt og samfunnsansvar: 1935-1969 (Vol. B. 2). Oslo: Pax forlag. 
Bjørnson, Ø., Kokkvoll, A., Sverdrup, J., et al. (1990). På klassekampens grunn: (1900-1920) (Vol. 2). Oslo: Tiden.

Crouch, C. (1993). Industrial Relations and European State Traditions. Oxford: Clarendon Press.

Due, J., Steen Madsen, J., \& Strøby Jensen, C. (1993). Den danske model: en historisk sociologisk analyse af det kollektive aftalesystem. København: Jurist- og økonomforbundets Forlag.

Falkum, E. (2015). Institutionalization and Dynamic Change of Institutions - the Basic Agreement and Tripartite Structures in Norway. In F. Engelstad \& A. Hagelund (Eds.), Cooperation and Conflict the Nordic Way: Work, Welfare, and Institutional Change in Scandinavia (53-76). Berlin: De Gruyter Open.

Howell, C. (2007). Trade Unions and the State: The Construction of Industrial Relations Institutions in Britain, 1890-2000. Princeton: Princeton University Press.

Justisdepartementet (1912). Ot.prp. nr. 29. (1912) Om utfærdigelse av en lov om arbeidstvister. Oslo: Justis- og Politidepartementet.

Martin, C. J., \& Swank, D. (2012). The Political Construction of Business Interests: Coordination, Growth, and Equality. Cambridge; New York: Cambridge University Press.

Moene, K. O., \& Wallerstein, M. (2006). The Scandinavian Model and Economic Development. Development Outreach, 8, 18-35.

Nergaard, K. (2016). Framvekst og etablering av en offentlig meklingsinstitusjon. In N. Dalseide (Ed.), Fred er dog det beste. Oslo: Pax forlag.

Nergaard, K., Alsos, K., \& Seip, Å. A. (2016). Koordinering av lønnsdannelsen innen de nordiske frontfagsmodellene. Oslo: Fafo.

Nilsson, C.-A. (2001). Employer Strategies Against Unionism and Socialism 1899-1940. In H. Kryger Larsen (Ed.), Convergence?: Aspects on the Industrialisation of Denmark, Finland and Sweden 1870-1940 (157-197). Helsinki: Suomen Tiedeseura.

NOU (2013:13). Lønnsdannelsen og utfordringer for norsk økonomi: utredning fra et utvalg oppnevnt av regjeringen Stoltenberg II 14. desember 2012: avgitt til Finansdepartementet 3. desember 2013. Oslo: Departementenes servicesenter, Informasjonsforvaltning.

Olson, M. (1965). The Logic of Collective Action: Public Goods and the Theory of Groups. Cambridge Mass: Harvard University Press.

Olson, M. (1982). The Rise and Decline of Nations: Economic Growth, Stagflation, and Social Rigidities. New Haven, Conn: Yale University Press.

Olson, M. (1990). How Bright are the Northern Lights? Some Questions about Sweden. Lund: Institute of Economic Research.

Olstad, F. (2010). Veien fram til Hovedavtalen 1899-1935. In T. Bergh (Ed.), Avtalt spill. (37-57). Oslo: LO Media.

Olstad, F., Hansen, S.-A., \& Aaslund, V. (2009). Med knyttet neve : 1899-1935 (Vol. B. 1). Oslo: Pax.

Ording, A. (1932). Norsk Centralforening for Boktrykkere. 1882-1932. Oslo: Arbeidernes Aktietrykkeri.

Ormestad, M., \& Arbeidernes faglige landsorganisasjon (1906). Skandinaviske arbeiderkongresser: beslutninger og resolutioner vedtagne ved de skandinaviske arbeiderkongresser $i$ Gøteborg 1886, i Kjøbenhavn 1888, i Kristiania 1890, i Malmø 1892, i Stockholm 1897 og i Kjøbenhavn 1901. Kristiania.

Ormestad, M. (Ed.) (1906). Skandinaviske Arbeiderkongresser. Beslutninger og resolutioner. Kristiania: Arbeidernes Aktietrykkeri.

Petersen, E. (1950). Norsk arbeidsgiverforening: 1900-1950. Oslo: Grøndahl \& Søns Boktrykkeri.

Pierson, P. (2004). Politics in Time: History, Institutions, and Social Analysis (Kindle ed.). Princeton and Oxford: Princeton University Press

Pollard, S. (1981). Peaceful Conquest: The Industrialization of Europe, 1760-1970. Oxford; New York: Oxford University Press.

Seip, A.-L. (1981). Om velferdsstatens framvekst: artikler. Oslo: Universitetsforlaget.

Seip, Å. A. (2013). Bruk av tvungen lønnsnemnd i Norge 1990-2012. Oslo: Fafo. 
Stokke, T. A. (1997). Lønnsforhandlinger og konfliktløsning. Norge i et skandinavisk perspektiv (Ph.D. Thesis). Oslo: Fafo.

Terjesen, E. A. (2010). Kompromiss, allianse eller kamp: Hvorfor har vi en hovedavtale? In T. Bergh (Ed.), Avtalt spill. (59-87). Oslo: LO Media.

Undén, Ö. (1912). Kollektivavtalet enligt gällande svensk rätt. Lund: Lindstedts Univ. Bokhandel. Voldgiftskomitéen (1909). Forslag til lov om mægling og voldgift i arbeidstvister med motiver. Kristiania: Justis- og politidepartementet.

Weber, M. (1964). The Theory of Social and Economic Organization. New York: Free Press. 